Transatlantica

A T L A N T I C A

Revue d'études américaines. American Studies Journal

revue d'études américaines

$2 \mid 2016$

Ordinary Chronicles of the End of the World

\title{
Allyson Hobbs, A Chosen Exile : A History of Racial Passing in American Life
}

Lawrence Aje

revues.org

Publisher

AFEA

Electronic version

URL: http://transatlantica.revues.org/8417

ISSN: 1765-2766

Electronic reference

Lawrence Aje, «Allyson Hobbs, A Chosen Exile : A History of Racial Passing in American Life »,

Transatlantica [Online], 2 | 2016, Online since 14 September 2017, connection on 19 October 2017.

URL : http://transatlantica.revues.org/8417

This text was automatically generated on 19 October 2017

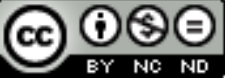

Transatlantica - Revue d'études américaines est mis à disposition selon les termes de la licence

Creative Commons Attribution - Pas d'Utilisation Commerciale - Pas de Modification 4.0 International. 


\section{Allyson Hobbs, A Chosen Exile: A History of Racial Passing in American Life}

Lawrence Aje

\section{REFERENCES}

Hobbs, Allyson, A Chosen Exile: A History of Racial Passing in American Life, Cambridge, MA : Harvard University Press, 2014, 382 pp. , € 27.00, ISBN 9780674368101

1 The last two decades have seen a considerable increase of publications on the issue of racial passing in the United States. Some studies have examined racial passing through personal or family stories (O'Toole ; Sharfstein ; Williams). Others have sought to adopt a quantitative and synchronic approach to the phenomenon (Nix \& Qian ; Mill \& Stein) or to analyze how cases of racial passing were litigated in courts (Kennedy; Gross). A number of edited volumes have recently focused on the cinematic and literary representations of racial passing in American popular culture, whereas some studies have been keen on expanding the notion by examining instances of ethnic or gender passing (Dawkins; Gayle ; Ginsberg; Wald ; Nerad).

2 Yet, in this flurry of publications, Allyson Hobbs's A Chosen Exile: A History of Racial Passing in American Life, is a valuable contribution that distinguishes itself as the first full-length historical monograph to comprehensively tackle and complicate this sensitive and emotionally charged topic. This ambitious study is a revised version of Hobbs's 2009 dissertation in history which she defended at the University of Chicago.

3 A Chosen Exile historicizes the practice of racial passing in the United States, by outlining, from the period of slavery to the early 1970s, how fair-skinned Blacks, whom the author designates as "racially ambiguous individuals", managed to navigate the troubled waters of race undetected. In keeping with the findings of her predecessors, Hobbs confirms that 
the main reason that motivated racial passing was social advancement. Hobbs however differentiates herself from other scholars who have, according to her, paid far more attention to the benefits derived from passing as White instead of focusing on what she deems is a more fundamental and hitherto neglected aspect of the practice, namely, that by leaving their colored relatives or friends behind, passing translated into a loss of intraracial sociability and, to some extent, the loss of one's self. A Chosen Exile is underpinned by two intertwined objectives: a historical examination of the personal motivations behind racial passing and a simultaneous assessment of the consequences of rejecting one's "black racial identity" (11) - an act Hobbs qualifies as being tantamount to a racial exile.

4 Hobbs dismisses our commonly held assumptions about a lack of archival evidence that would limit our understanding of the phenomenon of racial passing. She manages to piece together a general history of racial passing in the United States by relying on a set of disparate primary and secondary sources such as private letters, family histories, newspaper advertisements, novels, as well as correspondence between authors and their publishers. By mining such a wide array of sources, Hobbs successfully manages to shed light on a practice that was meant to remain hidden.

5 A Chosen Exile starts with a prologue, which serves as a general introduction, and is composed of five chapters of approximately the same length (i.e., approximately fifty pages each). Each chapter covers a historical period and features case studies, generally in the form of an analysis of personal or family trajectories. The book is interspersed with useful illustrations that allow the reader to visually associate the historical actors under discussion with their phenotypic features. A Chosen Exile is a well-researched book, which has close to 82 pages of notes. The monograph ends with acknowledgments and a very handy and well-organized thematic and proper name index.

Chapter 1, "White is the Color of Freedom", focuses on the history of passing before the general abolition of slavery in the United States in 1865. The implementation and rigid enforcement of the one-drop rule which accompanied the legal codification of racial slavery, provided that an individual's legal status - bond or free, free white or free person of color -would be predicated on any visible or known black lineage. Hobbs argues that, during slavery, racial passing was, first and foremost, a means to escape bondage rather than a desire to deny one's black ancestry. Hobbs identifies the 1820s as a turning point after which "passing as free gave way to the phenomenon of passing as white" (42) - a shift she attributes to the increasing tightening of the socio-racial order. Building on Ariela Gross's work on the performative nature of race and race litigations during the antebellum period, this chapter reveals how light-skinned slaves sought to challenge their enslavement in courts on the grounds that they were unlawfully held in bondage. As racial passing raised concerns about racial purity and miscegenation, the whole white community, by means of popular juries and witnesses, policed racial boundaries in the courts. Yet, as race could not always be determined by physical inspection, racially ambiguous individuals were expected to meet a number of requirements to be considered white. Demonstrating behaviors or enjoying rights which were commonly associated with white people such as voting, being articulate, literate or well-dressed, influenced the jury's decision to assign, or deny, an individual the white racial (and legal) status. Hobbs concludes this aptly titled first chapter by arguing that miscegenation ultimately undermined the socio-racial hierarchy as light-skinned offspring took advantage of the prejudicial association of servility with black skin. To 
illustrate her point, Hobbs provides the reader with striking examples of fair-skinned slaves, such as Ellen Craft or Henry Bibb, who were able to simply walk off to freedom by assuming the "airs of importance" of their white masters.

7 Chapter 2, "Waiting on a White Man's Chance", focuses on the period of Reconstruction and the advent of Jim Crow. In the aftermath of the Civil War, some African Americans believed that the prevalence of racism in the United States would hinder their integration and chose to migrate to Liberia. However, much as during the antebellum period, the majority of Blacks, who identified as colored Americans and rejected any link to Africa, felt it was time to demand full citizenship. The post Civil War period was characterized by an increased geographic mobility for the African-American southern population. Emancipated slaves massively left rural regions to settle in developing southern and northern urban centers where they could land jobs. This migration translated into greater social mobility. Hobbs contends that, during Reconstruction, fair-skinned blacks did not see the need to pass, as more social and political opportunities were made available to them in what she describes as "America's first experiment in creating a 'postracial' society" (74). To prove her point, she examines the personal trajectories of notable light-skinned Black politicians and their spouses (Josephine and Blanche Bruce, P.B.S Pinchback) who chose not to pass and how these fair-complected individuals were received in Washington D. C. circles. Hobbs also devotes a significant passage of this chapter to light-skinned writer Charles Chesnutt, an octoroon who also chose not to pass but who sought to complicate the black/white dialectical racial opposition by envisaging the possibility of a "new race".

The second half of chapter 2 discusses the end of Reconstruction and the extent to which the 1896 Supreme Court case of Plessy v. Ferguson was the fulcrum point which paved the way for the extension of de jure racial segregation in the United States. The implementation of Jim Crow laws put an end to the optimism engendered by the possibility of greater fluidity in race relations that had characterized Reconstruction. As discriminatory practices based on race became generalized and severely curtailed economic opportunities, racially ambiguous individuals increasingly chose to pass, in order to work as whites in white-collar, or white only, jobs.

9 Chapter 3, "Lost Kin", covers the time period from the 1890s to the 1920s. It examines how the generalization of legally endorsed racial discrimination was enforced by violence and not only led to the disenfranchisement of African-Americans, by way of different restrictive measures, but also to their migration. The settlement of African-Americans in large anonymous cities, during the Great Migration of the 1910s, encouraged a growing number of light-skinned blacks to pass in the work place or when they attended college. While some individuals passed permanently, others chose to do so only temporarily in a practice known as "nine to five passing". Hobbs explains that passing temporarily, in order to benefit from a wider range of economic choices, still came at a cost. These individuals could not be seen commuting from their black neighborhoods and sometimes had to ignore black relatives or friends in public. Although it sometimes happened, passers were rarely betrayed by other African-Americans who had detected their black lineage.

10 In reaction to the threat of passing, southern authorities adopted stricter legislation to preserve racial integrity and to prevent miscegenation. For example, whereas antebellum Virginia law had enabled an individual to be considered as white beyond a certain degree of racial mixing, in 1924, the state's legislature provided that, henceforth, only those who 
bore "no trace of other blood" could claim the status of a white person. Hobbs recounts how, in the 1920s, eugenicists such as Walter A. Plecker, a physician and the state registrar of Virginia, adamantly strove to police the color line by investigating individuals suspected of trying to pass as white. These suspected passers sometimes claimed a Native American heritage, as the Virginia law allowed people with $1 / 16^{\text {th }}$ Indian ancestry to be classified as white. In this fascinating section of chapter 3, we learn that midwives were sometimes subject to investigation for having voluntarily racially misclassified black babies to enable them to "pass off" as whites. This little known and surprising practice contradicts the common assumption that racial passing was an act which was necessarily undertaken by an individual on his own volition, or at the instigation of a close relative, thereby giving the process a collective nature.

In chapter 4, entitled "Searching for a New Soul in Harlem", Hobbs examines the different and sometimes complex relationship of three major authors (Jean Toomer, Nella Larsen and Langston Hughes) to African-American identity. Hobbs argues that the Harlem Renaissance, just as Reconstruction, offered alternative responses to racial passing. Contrary to the past, African-Americans who were now portrayed in a more positive light, as artists and intellectuals, sought to create a new race that stemmed out of black folk culture. The Harlem Renaissance opened up "new discussions for racial ambiguity and new possibilities for racial identification" (177), most notably by allowing the recognition of mixed-race identities. During that era, rejecting a black racial identity did not necessarily translate into passing as white. The time was thus propitious to a more inclusive racial identity that departed from the either/or racially binary exclusive perspective. Yet, quite surprisingly, whereas the period was more accepting of racial ambiguity, the theme of racial passing became very popular in literature and in musicals. In addition, although African-American identity underwent a refashioning during the Harlem Renaissance, prevailing ideas about race prevented the emergence of a new and more complex African-American identity as individuals, regardless of their very light skin complexion, were still lumped together with the black group and expected to express themselves and behave in certain ways.

12 As the title of the last chapter suggests, "Coming Home" examines how between the Great Depression and the early Civil Rights Movement, more specifically from 1932 to 1947, more and more light-skinned Blacks who had chosen to pass "returned to the race", in what Hobbs describes as a "critical turning point in the history of passing" (220). The desegregation of public housing and facilities, of the military and of the police, of juries, sports teams and primary elections, were among many significant social and political advances brought about by World War II and the Civil Rights Movement that allowed individuals to live as Blacks, as well as citizens, at the same time. In this context of civil rights activism, and of social, political and economic progress for African-Americans, the practice of passing was disavowed and considered to be an extreme act of treachery. According to Hobbs, by the 1970s, many African-Americans perceived passing as "a relic of the past" (263).

Chapter 5 focuses largely on the story of Albert Johnston's family, a fair-skinned AfricanAmerican physician who chose to pass with his family, before finally revealing his black racial identity in the late 1940s and becoming an outspoken civil rights activist. The Johnston family's skin complexion was brown enough to cast doubts on their racial origin. Yet the family's deportment and social status enabled its acceptance by white neighbors. Hobbs analyzes how the Johnston family's story of passing made the headlines 
of the press by convincingly showing that magazines such as The Reader's Digest, Life, Look and Ebony all sought to make a profit out of their readership's fascination with this sensitive subject. Quite interestingly, these magazines also showcased this sensational story as it served as an encouraging sign of the racial liberalism and tolerance of the Johnstons' white neighbors, which signaled better days ahead, in terms of racial integration.

Hobbs concludes her study with an epilogue that overviews contemporary discourses on race and how the possibility of identifying as mixed-race in the $21^{\text {st }}$ century, in the context of Barack Obama's historic 2008 election, has broadened (African-)Americans' racial options.

By following the personal trajectories of those who passed and by crafting a collective history of racial passing, Hobbs sheds light on a phenomenon which has hitherto never been analyzed with such scope and depth. One of the greatest achievements of A Chosen Exile is to historicize the phenomenon of racial passing by showing how the practice evolved through time. By situating stories of passing in their historical context, Hobbs examines the specific geographic, social, economic, and political variables, which fostered the practice as well as the stakes it raised. A Chosen Exile examines the tension between the performative and constitutive aspect of race. It also stresses how subjectivity can be influenced and constructed by one's social perception. Hobbs successfully demonstrates how challenging one's ascribed racial status was a subversive act which proved to be dangerous as it equated to usurping a racial identity one was not legally entitled to. Hobbs provides a perfect illustration of the vulnerability of the passers by shedding light on the unknown phenomenon of racial outing, whereby, in the 1940s, the black press sought to expose the racial identity of individuals, such as Elsie Roxborough, who tried to pass (139). She also conclusively reveals how passing was sometimes an open secret that was protected by employers, coworkers, neighbors and friends as long as the passer behaved appropriately.

Hobbs does not shy away from broaching controversial aspects of racial passing by arguing that one of the reasons for the prevalence of the practice was political and economic opportunism. And, interestingly enough, whereas Hobbs implies that once an individual passed "there was simply no turning back" (4), she contradicts herself in many instances by brilliantly documenting how some passers chose to "return home" to their race. One striking example provided by Hobbs is the trajectory of Syphax who changed his name to McKee and decided to pass after he graduated from Columbia Law school in 1902. After having married a white woman and spent his whole career working as a prominent Wall Street lawyer, he chose to cross the color line again in 1940 in order to inherit a large fortune left by his black grandfather.

Despite its many qualities, A Chosen Exile presents some argumentative weaknesses. Contrary to recent research undertaken by Emily Nix and Nancy Qian that has used information extracted from the US census between 1880 to 1940 to quantify the extent of the practice of racial passing by measuring the percentage rate of black men who passed for white between each census interval or Mill and Stein's ongoing analysis which has sought to identify all siblings who passed for white over a thirty year period, by using a sample of 12,000 African-American families whose digitized records were matched across the 1910 and 1940 censuses, in Hobbs's study, the exact number of those who chose to pass can only be guessed at. Indeed, Hobbs's statement whereby between the "late eighteenth and the mid-twentieth centuries, countless African Americans passed as 
white" (4) would need more additional empirical and quantitative evidence to be substantiated.

Consequently, the representativeness of Hobbs's corpus may sometimes be questioned. For instance, in chapter four, Hobbs limits her analysis of racial passing to three literary actors of the Harlem Renaissance, thereby ignoring the phenomenon in society at large in those years. In the same vein, one may question the extent to which the Johnstons' exceptional story can be seen as representative and exemplary as it only provides a window on a family's experience. Hobbs's choice to include a fictional character from Frank J. Webb's 1858 novel as a comparative referent to historical actors is also puzzling (64-67).

's interchangeable use of African-American and Black problematically partakes in sustaining mutually exclusive racial categories by reinstating the one-drop rule that has characterized the United States' approach to racial classification. It could also be argued that equating racial passing with a loss somewhat paradoxically perpetuates the longstanding trope that has prevailed in the tragic mulatto literature. A final regret is that A Chosen Exile does not study how affirmative action policies not only diminished the need for racial passing, but also encouraged racially ambiguous individuals to take advantage of their black ancestry. Including this aspect in her study would have enabled Hobbs to examine the issue of "soulmaning", a practice whereby whites have claimed an African-American ancestry and passed as Blacks in order to broaden their educational or professional opportunities.

Despite these minor criticisms, A Chosen Exile is on the whole a convincing study that provides important insights into the evolution of racial identity politics in the United States. In so doing, Hobbs addresses the relatively neglected issue of changing patterns of group identity in the African-American population, a group which has often been perceived as racially monolithic. One of the great merits of this monograph is to place the phenomenon of racial passing in the general history of the United States and to inscribe it in the conversation on race that has fundamentally structured the country's power relations. For all these reasons, Hobbs's A Chosen Exile is a landmark contribution to the scholarship on racial passing in the United States that will prove of invaluable benefit to both scholars and to the general public.

\section{BIBLIOGRAPHY}

Works cited

DAWKINS, Marcia A., Clearly Invisible : Racial Passing and the Color of Cultural Identity, Waco, Tex., Baylor University Press, 2012.

GINSBERG, Elaine K.,, ed. Passing and the Fictions of Identity, Durham, NC, Duke University Press, 1996.

GROSS, Ariela J., What Blood Won't Tell : A History of Race on Trial in America, Cambridge, Mass., Harvard University Press, 2008. 
KENNEDY, Randall L., “Racial Passing.” Ohio State Law Journal 62, no. 31145 (2001) : 1-28.

NERAD, Julie Cary, ed., Passing Interest : Racial Passing in US Novels, Memoirs, Television, and Film, 1990-2010, Albany, State University of New York Press, 2015.

O’TOOLE, James M., Passing for White : Race, Religion, and the Healy Family, 1820-1920, Amherst, University of Massachusetts Press, 2002.

NIX, Emily \& QIAN, Nancy, “The Fluidity of Race : 'Passing' in the United States, 1880-1940”, National Bureau of Economic Research Working Paper No. 20828, January 2015, 1-75.

Mill, Roy \& Stein, C.D. Luke. "Race, Skin Color, and Economic Outcomes in Early TwentiethCentury America” working paper, Stanford University, November 2012, 1-53.

Sharfstein, Daniel J. The Invisible Line : Three American Families and the Secret Journey from Black to White. New York : Penguin Press, 2011.

Wald, Gayle. Crossing the Line : Racial Passing in Twentieth-Century U.S. Literature and Culture New Americanists. Durham N.C. : Duke University Press, 2000.

Williams, Gregory H. Life on the Color Line: The True Story of a White Boy Who Discovered He Was Black. New York, N.Y. : Dutton, 1995.

\section{AUTHORS}

\section{LAWRENCE AJE}

Université Paul-Valéry Montpellier 3 